ISSN 1045-6333

\title{
AVOIDING SUBOPTIMAL BEHAVIOR \\ IN INTELLECTUAL ASSET TRANSACTIONS: \\ ECONOMIC AND ORGANIZATIONAL PERSPECTIVES ON THE SALE OF KNOWLEDGE
}

\author{
Gavin Clarkson
}

Discussion Paper No. 330

$6 / 2001$

Harvard Law School

Cambridge, MA 02138

The Center for Law, Economics, and Business is supported by a grant from the John M. Olin Foundation.

This paper can be downloaded without charge from:

The Harvard John M. Olin Discussion Paper Series: http://www.law.harvard.edu/programs/olin_center/ 
JEL Class: D23, D45, G12, K11, L65

\title{
Avoiding Suboptimal BeHAVior in InTELlectual ASSET Transactons: Economic and Organizational Perspectives on the Sale of KNOWLEDGE
}

\author{
Gavin Clarkson*
}

\begin{abstract}
Although some of the most important elements of a knowledge-based economy in the coming century will be intellectual asset transactions, the current marketplace for intellectual asset transactions is murky at best. With patent litigation costs skyrocketing, most organizations have only recently begun licensing and cross-licensing their intellectual asset portfolios. Because robust valuation metrics for intellectual assets have not been fully developed, most licensing negotiations are based on rules of thumb rather than quantitative methods, rules of thumb that can often be economically disadvantageous to either the licensee or the licensor. With only two percent of the millions of innovations created in this country utilized under license, billions of dollars worth of intellectual assets are underutilized.
\end{abstract}

Economic theory might suggest that the information necessary for quantitative analysis is too costly to acquire (i.e. difficult to obtain or not available at all), resulting in a relatively small number of market transactions involving intellectual assets, with valuations generally covered by rules of thumb. Different organizational behavior theories would probably suggest that some forms of bounded rationality are responsible for the use of these rules of thumb. The true answer probably lies somewhere in the middle of the spectrum between those perspectives.

This article explores the nature of intellectual assets and the dynamics of intellectual asset transactions. After examining various organizational behavior and economic perspectives in search of an explanation for the current state of the marketplace for intellectual asset transactions, the article concludes by proposing valuation metrics that might better inform the negotiations surrounding an intellectual asset transaction.

(C) 2001 Gavin Clarkson. All rights reserved.

\footnotetext{
*Olin Fellow in Law, Economics, and Business and KPMG Fellow at the Harvard Business School. The author would like to thank Professors Lynda Applegate, Lee Fleming, Joni Hersch, Howell Jackson, Josh Lerner, Jay Lorsch, and Kathleen Valley for their thoughtful comments on various portions of this manuscript during its development. Tom Arnold, Bryan Benoit, Karen Copenhaver, and Bob Curfiss also provided invaluable feedback and perspectives as experienced practitioners in the intellectual asset marketplace.
} 


\title{
Avoiding Suboptimal BeHAVIOR IN INTELLECTUAL ASSET TRANSACTONS: ECONOMIC AND ORGANIZATIONAL Perspectives on the SAle OF KNOWLedge
}

\author{
Gavin Clarkson*
}

TABLE OF CONTENTS

I. INTRODUCTION $\ldots \ldots \ldots \ldots \ldots \ldots \ldots \ldots \ldots \ldots \ldots \ldots \ldots \ldots \ldots \ldots \ldots$

II. BACKGROUND ........................ 4

A. The Nature of Intellectual Assets . . . . . . . . . . 5

B. The Nature of Intellectual Asset Transactions . . . . . . . . 7

III. Possible Explanations $\ldots \ldots \ldots \ldots \ldots \ldots \ldots \ldots \ldots \ldots$

A. Economic Perspective .................... 11

B. Organizational Behavior Perspective $\ldots \ldots \ldots \ldots \ldots$

IV. Possible IMPRovements $\ldots \ldots \ldots \ldots \ldots \ldots$

A. Theoretical Basis ....................... 19

B. Proposed Methodology ..................... 22

1. Contribution to Profit of Intangible

Assets (CPIA) ..................... 23

2. Contribution to Profit of Intellectual

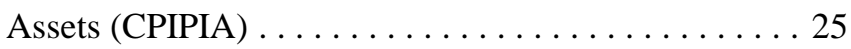

C. Empirical Analysis and Validation of Metrics ....... 25

D. Application of the CPIPIA Metric ............ 27

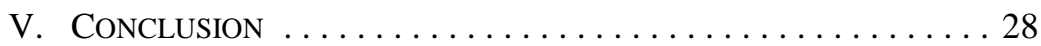

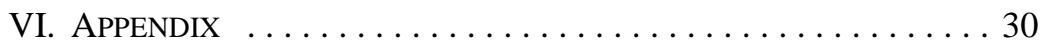

(C) 2001 Gavin Clarkson. All rights reserved.

* Olin Fellow in Law, Economics, and Business and KPMG Fellow at the Harvard Business School. 


\title{
Avoiding Suboptimal BEHAVIOR IN INTELLECTUAL ASSET TRANSACTONS: ECONOMIC AND ORGANIZATIONAL Perspectives on The SAle OF KNOWLEDGe
}

\author{
Gavin Clarkson*
}

(C) 2001 Gavin Clarkson. All rights reserved.

\section{INTRODUCTION}

An oft-quoted rule of thumb suggests that of ten laboratory inventions, only one will receive a patent; only one in ten patents will be licensed by a company, and only one in ten licenses results in more than $\$ 25,000$ per year in income ${ }^{1}$

Although some of the most important elements of a knowledgebased economy in the coming century will be intellectual asset transactions, the current marketplace for these transactions is murky at best. While patent litigation costs are skyrocketing, most organizations have only recently begun licensing and cross-licensing their intellectual asset portfolios. Because robust valuation metrics for intellectual assets have not been fully developed, most licensing negotiations are based on rules of thumb rather than quantitative methods - rules of thumb that are often economically

disadvantageous to either the licensee or the licensor. ${ }^{2}$ With only two percent of the millions of innovations created in this country utilized under license, ${ }^{3}$ billions of dollars worth of intellectual assets are underutilized. Such a situation leads to the obvious question ... why?

* Olin Fellow in Law, Economics, and Business and KPMG Fellow at the Harvard Business School.

1. See Katherine Bouton, Academic Research and Big Business: A Delicate Balance, N.Y. TIMES, Sept. 11, 1983, § 6 (Magazine), at 62, 123.

2. Several of these rules of thumb are discussed in detail in Part II.B, infra.

3. Cf. John Milward, A Five-Year Journey to a Better Mousetrap, N.Y. TIMES, May $24,1998, \S 3$, at 8 ("[O]nly 2 percent of all patents are ever licensed to major corporations."). 
Economic theory suggests that the information necessary for quantitative analysis is too costly to acquire (i.e., difficult to obtain or not available at all), resulting in a relatively small number of wellvalued market transactions involving intellectual assets, with most valuations generally covered by rules of thumb. Different organizational behavior theories suggest that some form of bounded rationality is responsible for the use of these rules of thumb. The true answer probably lies somewhere between these perspectives.

Parties to intangible asset licensing negotiations need a better set of metrics to enable them to reach successful technology licensing agreements. Much of the available economic literature on licensing, while theoretically sound, is neither empirically based nor instructive on how to develop an industry-based metric for royalty rates. ${ }^{4}$ The literature on patents, R\&D expenditures, and market value is also informative but does not provide clear guidance for examination of actual royalty rate provisions. Significant literature exists regarding economic examination of patents, ${ }^{5}$ patent counts, ${ }^{6}$ comparisons of patents and $\mathrm{R} \& \mathrm{D},{ }^{7}$ and evaluating returns from intellectual assets. ${ }^{8}$

4. See Nancy T. Gallini, Deterrence by Market Sharing: A Strategic Incentive for Licensing, 74 AM. ECON. REV. 931 (1984); Nancy T. Gallini \& Ralph A. Winter, Licensing in the Theory of Innovation, 16 RAND J. ECON. 237 (1985); Morton I. Kamien $\&$ Yair Tauman, Fees Versus Royalties and the Private Value of a Patent, 101 Q.J. ECON. 471 (1986); Michael L. Katz \& Carl Shapiro, How to License Intangible Property, 101 Q.J. ECON. 567 (1986); Michael L. Katz \& Carl Shapiro, On the Licensing of Innovations, 16 RAND J. ECON. 504 (1985).

5. See, e.g., C.T. TAYlor \& Z.A. Silberston, The EConomic ImpaCt of the PATENT System: A StUdy OF THE BRITISH EXPERIENCE (1973); Zvi Griliches, Patent Statistics as Economic Indicators: A Survey, 28 J. ECON. LITERATURE 1661 (1990); Zvi Griliches, Patents: Recent Trends and Puzzles, 1989 BROOKINGS PAPERS ON ECON. ACTIVITY 291; Zvi Griliches et al., The Value of Patents as Indicators of Inventive Activity, in ECONOMic Policy And TeChnological Performance 97 (Partha Dasgupta \& Paul Stoneman eds., 1987); F.M. Scherer, Firm Size, Market Structure, Opportunity, and the Output of Patented Inventions, 55 AM. ECON. REV. 1097 (1965); Jacob Schmookler, Economic Sources of Inventive Activity, 22 J. ECON. HIST. 1 (1962).

6. See, e.g., Jerry Hausman et al., Econometric Models for Count Data with an Application to the Patents-R \& D Relationship, 52 ECONOMETRICA 909 (1984); Jean Olson Lanjouw et al., How to Count Patents and Value Intellectual Property: The Uses of Patent Renewal and Application Data, 46 J. INDUS. ECON. 405 (1998).

7. See, e.g., John Bound et al., Who Does $R \& D$ and Who Patents?, in R \& D, Patents, AND Productivity 21 (Zvi Griliches ed., 1984); Zvi Griliches, Market Value, $R \& D$, and Patents, in $\mathrm{R} \& \mathrm{D}$, PATENTs, AND PRoductivity 249 (Zvi Griliches ed., 1984); Bronwyn H. Hall et al., Patents and $R$ and D: Is There a Lag?, 27 INT'L ECON. REv. 265 (1986); Ariel Pakes \& Zvi Griliches, Patents and R \& D at the Firm Level: A First Look, in R \& D, PATENTS, AND PRODUCTIVITY 55 (Zvi Griliches ed., 1984).

8. See, e.g., Zhen Deng et al., Science and Technology as Predictors of Stock Performance, Fin. ANALYSTS J., May-June 1999, at 20; Zvi Griliches et al., $R \& D$, and Patents, and Market Value Revisited: Is There a Second (Technological Opportunity) Factor?, 1 ECON. INNOVATION \& NEW TECH. 183 (1991); Bronwyn H. Hall, Innovation and Market Value, in Productivity, InNOVATION AND ECONOMIC PERFORMANCE (Ray 
Yet, other than a small number of empirical studies, ${ }^{9}$ little or no indepth examination of royalty rate calculations has been performed.

Several authors, as well as jurists, however, have suggested that a good, industry-specific metric for use in royalty rate negotiations would be based on the difference between the aggregate earnings rates from companies with intellectual asset portfolios and the aggregate earnings rates from companies without such portfolios. ${ }^{10}$ Parr \& Sullivan and Smith \& Parr $^{11}$ in particular have suggested that such a metric could be derived from the well-established financial measure known as the Weighted Average Cost of Capital, but a specific metric has never been reduced to a workable form.

Part II of this article presents some background on the nature of intellectual assets and the dynamics of intellectual asset transactions. Part III examines various organizational behavior and economic perspectives in search of possible explanations for the current state of the marketplace for intellectual asset transactions. Part IV offers possible improvements by proposing valuation metrics that might better inform the negotiations surrounding an intellectual asset transaction.

\section{BACKGROUND}

Barrell et al. eds., 2000); Richard C. Levin et al., Appropriating the Returns from Industrial Research and Development, 1987 BROOKINGS PAPERS ONECON. ACTIVITY 783; Ariel Pakes, On Patents, $R \& D$, and the Stock Market Rate of Return, 93 J. PoL. ECON. 390 (1985); Bronwyn H. Hall et al., Market Value and Patent Citations: A First Look, NBER Working Paper No. 7741 (2000).

9. See TAYloR \& Silberston, supra note 5; Bharat N. Anand \& Tarun Khanna, The Structure of Licensing Contracts, 48 J. InDUS. ECON. 103 (2000); Ashish Arora, Patents, Licensing, and Market Structure in the Chemical Industry, 26 RES. POL'Y. 391 (1997); Christian Bessy \& Eric Brousseau, Technology Licensing Contracts Features and Diversity, 18 INT'L REV. LAW \& ECON. 451 (1998); Richard E. Caves et al., The Imperfect Market for Technology Licenses, 45 OXFORD BULL. ECON. \& STAT. 249 (1983); Stephen A. Degnan \& Corwin Horton, A Survey of Licensed Royalties, LES NOUVELLES, June 1997, at 91; Inés Macho-Stadler et al., The Role of Information in Licensing Contract Design, 25 RES. POL'Y. 43 (1996); M.D. Rostoker, PTC Research Report: A Survey of Corporate Licensing, 24 IDEA 59 (1983).

10. See TWM Mfg. Co. v. Dura Corp., 789 F.2d 895 (Fed. Cir. 1986); GeorgiaPacific Corp. v. United States Plywood Corp., 318 F. Supp. 1116 (S.D.N.Y. 1970); Russell L. Parr \& Patrick H. Sullivan, Technology Licensing: Corporate Strategies for MaXimizing Value (1996); Gordon V. SMith \& Russell L. Parr, VALUATION OF INTELLECTUAL PROPERTY AND INTANGIBLE ASSETS (3d ed. 2000); Lauren Johnston Stiroh \& Richard T. Rapp, Modern Methods for the Valuation of Intellectual Property, in Protecting Your InTEllectual Property ASSETS 171 (PLI Pats., Copyrights, Trademarks, and Literary Prop. Course, Handbook Series No. 526, 1998); Richard S. Toikka, Patent Licensing Under Competitive and Non-Competitive Conditions, 82 J. PAT. \& TRADEMARK OFF. SOC'Y 279 (2000).

11. PARR \& SUlLIVAN, supra note 10; SMITH \& PARR, supra note 10. 
The balance sheet of a successful company occasionally includes an entry for Intangible Assets. Given the microscopic level of study devoted to other elements of a company's financial statement, it is surprising to note the scant attention given to intangible assets. Nevertheless, the information economy includes numerous companies whose value is almost entirely based on intangible assets. ${ }^{12}$ More often than not, the value of these intangible assets is not reflected anywhere in a company's financial statements.

Intellectual assets, a subset of intangible assets, have become one of the most important commodities in our globally connected economy, accounting for "more than 20 percent of world trade, or approximately US $\$ 740$ billion." 13 Despite the importance of intellectual asset transactions it would seem they are often the least understood of all types of economic transactions, and perhaps the most poorly managed. A closer look at the nature of intellectual assets may provide a better understanding of these transactions.

\section{A. The Nature of Intellectual Assets}

Intellectual property (IP) is a primary class of intangible assets. More specifically, it is intangible property that has some form of legal protection. Intellectual property law identifies five major sources of legal protection: patents, trademarks, industrial designs, confidential information/trade secrets, and copyright. ${ }^{14}$ In general, patents protect inventions, such as new medicines or new processes for making something. Trademark law protects words, names, symbols, pictures, logos, designs, or shapes associated with a product (for instance, the words "Coca-Cola" or "Microsoft"). Industrial designs protect the aesthetic appearance of a product rather than its functional features. Trade secret law protects concepts, ideas, and factual information kept in confidence, such as customer lists or the idea for a computer program. Copyright law, the last major area of protection, deals with protection of ideas; however, copyright law differs from other forms of intellectual property protection in that it protects the expression of an idea rather than the idea itself.

12. Microsoft's intellectual property and intangible assets account for almost $95 \%$ of its market value. See Gavin Clarkson \& LYNDA APPLEGATE, InTELlECtUAL AsSET VALUATION 2, 15 ( Harv. Bus. School Pub. No. 801-192, 2000).

13. Lesley Ellen Harris, Digital Property: CuRrenCy of the 21St Century 51 (1998).

14. Certain countries, including the United States, have created additional areas of specialized intellectual property protection such as photolithography masks and plant variety patents. See 17 U.S.C $\$ 901-914$ (1994) (photoilthography masks); 7 U.S.C. $\S$ 2321-2582 (1994) (plant variety protection). 
Companies with high valuations based on intangible assets tend to be innovative, but the study of innovation is not an exact science. Many economists have tried to quantify innovation using patents as surrogates. ${ }^{15}$ One potential shortcoming of focusing on patents as a measure of innovation, besides the fact that it ignores the other types of intellectual property, is that patents are often valueless absent the "know-how" that translates protected intellectual property into viable products. Innovation increases the value of intellectual property. Paul Cook, president of Raychem, described this process as "the real work-reducing the idea to practice [is] the drudgery part of innovation." 16 Conceptually, intellectual property, as the result of creativity, might be viewed as the invention while intellectual assets could be viewed as the innovations that, when combined with the invention, become a product.

This article refers to intellectual property and intellectual assets collectively as "IPIA". ${ }^{17}$ Intellectual capital includes IPIA as well as other informational and intangible assets. Whether shown on the balance sheet as intangible assets or not, these "invisible assets are the real source of competitive power and the key factor in corporate adaptability for three reasons: they are hard to accumulate, they are capable of simultaneous multiple uses, and they are both inputs and outputs of business activities."18

Expanding valuations beyond examining patents alone is one major difference between the viewpoint of the economist on innovation and that of the technologist. ${ }^{19}$ But even the technologist's

15. See, e.g., Hausman et al., supra note 6.

16. William Taylor, The Business of Innovation: An Interview with Paul Cook, HARV. Bus. REV., Mar.-Apr. 1990, at 96.

17. Because intangible assets and intellectual assets would both have the same acronym, and since the concept of intellectual assets almost always includes intellectual property, IPIA is used to refer collectively to intellectual property and intellectual assets.

18. Hiroyuki Itami \& Thomas W. Roehl, Mobilizing InVISible AsSETS 12-13 (1987).

19. For a discussion of the technologist's viewpoint, see William J. Abernathy \& Kim B. Clark, Innovation: Mapping the Winds of Creative Destruction, RESEARCH POLICY, Feb. 1985, at 3 and Rebecca M. Henderson \& Kim B. Clark, Architectural Innovation: The Reconfiguration of Existing Product Technologies and the Failure of Established Firms, ADMIN. SCI. Q., Mar. 1990, at 9. 
viewpoint is still constrained by the same fundamental problem: "[I]n the study of innovation and technical change in industry [there are no] satisfactory measures of new knowledge and its contribution to technological progress. There exists no measure of innovation that permits readily interpretable cross-industry comparisons." 20

Companies such as Dow Chemical have encouraged their employees to invent as much and generate as many patents as possible, without necessarily focusing on the strategic value of such activities. Dow "produced a lot of knowledge, patents, and intellectual property that did not create value" directly for Dow. ${ }^{21}$ But those same assets might be extremely valuable to other organizations.

The difficulty of measuring and valuing innovation as embodied in a company's intellectual assets becomes particularly apparent when a company wants to acquire another company or the rights to exploit its intellectual assets. In the absence of a standardized marketplace for intellectual assets, a company might not even be aware that it has an intellectual asset that is valued by another company. Even organizations that are aware of their intellectual assets may tend to choose royalty rates based on a rule of thumb rather than rates based on quantitative metrics or analyses of profitability. Before examining quantitative methods that can be employed to calculate royalty rates, it is necessary to explore the nature of intellectual asset transactions.

\section{B. The Nature of Intellectual Asset Transactions}

Unlike real estate, a given intellectual asset can be "sold" many times and to multiple entities and for use in different places simultaneously. This range of possibilities gives rise to a multitude of options for transferring rights to an intellectual asset. In general, rights can be either licensed or sold outright. A licensor exacts from a licensee a fee for the right to exploit in a defined way an asset to which the former retains ownership. In a sale, sometimes referred to as an assignment, the asset is transferred to a new owner. Owing to the uncertain absolute value of intellectual assets, licensing is far more common than sale unless the entire company is being sold.

Intellectual asset rights for a technology can be licensed individually or aggregated and licensed as a bundle. Licensing can be either exclusive (to only one licensee) or nonexclusive (to potentially multiple licensees). The scope of a license can be further limited

20. Wesley M. Cohen \& Richard C. Levin, Empirical Studies of Innovation and Market Structure, in 2 HANDBOOK OF INDUSTRIAL ORGANIZATION 1059, 1062 (Richard Schmalensee \& Robert D. Willig eds., 1989).

21. Gary A. Steinman, Conference Board, ReP. No. 1182-97-CH, MANaging, VALUING, AND PROTECTING INTELLECTUAL ASSETS 7 (1997). 
geographically, temporally, or by field of use. Additionally, licensees might be permitted to sublicense the rights to a technology and appropriate the benefits derived therefrom. Moreover, "most favored nation" status can guarantee specific licensees as good or better terms and conditions than are granted to other licensees.

Although quite different in many ways, the licensing of intellectual assets is still somewhat analogous to a real estate lease. The owner retains ownership of the property and assigns certain rights to another party for a defined period of time and in return receives compensation, monetary or otherwise. The similarity ends rather abruptly, however, when the task turns to determining what the compensation should be, particularly if it is solely monetary. Tom Arnold, one of the original founders of the Licensing Executives Society ("LES"), aptly described licensing as follows:

The licensing process is an art practiced in negotiation between two or more parties. The process is frequently difficult since its success requires that the parties agree on the exploitation of often highly valuable intellectual property rights in which both have, claim or want an interest. The range of interests, intellectual property rights, and exploitation arrangements is limitless, making the process of negotiating a mutually desirable agreement from the myriad possibilities indeed an art. $^{22}$

However "artistic" the negotiation of a license, the result is an agreement that affects both parties economically. More common than a lump sum license payment for a technology, particularly an unproven technology, is the negotiation of a royalty rate or contingent license fee on future earnings or sales. The negotiation literature clearly indicates a strong theoretical basis for using contingent contracts for transactions with high degrees of uncertainty, ${ }^{23}$ and the few empirical explorations of technology licensing agreements have found a high incidence of contingent contracts. ${ }^{24}$

22. Tom Arnold, Basic Considerations in Licensing, LES NOUVELLES, Sept. 1980.

23. See Max BAZERman, Judgment in Managerial Decision MaKing 125 (4th ed. 1998); MAX H. BAZERMan \& Margaret A. NeAle, Negotiating Rationally 95 (1992); Max H. Bazerman \& James J. Gillespie, Betting on the Future: The Virtues of Contingent Contracts, HARV. Bus. ReV., Sept.-Oct. 1999, at 155.

24. See Intellectual Prop. Research Assocs., The Royalty Rate Report For Pharmaceuticals \& BioteChNOlogy (3d ed. 1996); TAYlor \& Silberston, supra note 5; Anand \& Khanna, supra note 9; Bessy \& Brousseau, supra note 9; Caves et al., supra note 9 . Note that the royalty rates themselves were not analyzed in these studies. 
If a lump sum arrangement is used, either instead of or in addition to a royalty rate, the amount of the payment is usually based on the present value of a stream of royalty payments. The challenge in any of these transactions is thus to determine what the appropriate royalty rate should be. The rate should approximate, as nearly as possible, the fair rate of return on the intellectual asset rights that are to be transferred. Historically, intellectual asset licenses have rarely used significant quantitative analysis and have instead relied on common rules of thumb. Another founder of LES, Robert Goldscheider, has long been a proponent of one of the more common rules of thumb, the 25 percent rule:

The 25 Percent Rule originally occurred to [me] as a result of a series of successful commercial licenses with which [I] became involved back in the late 1950s. ... Having noticed [an] empirical relationship whereby there was a 25-75 split in the pre-tax profitability rate in a series of successful licenses, [I] developed a methodology that has proven its worth over the years in commercial negotiations. One starts with a 25 percent split [of the pre-tax profits] to the licensor and then either "tunes" this figure up or down, depending on the peculiar circumstances of each case $\ldots . .25$

In an empirical examination of royalty rates for a variety of technologies, the Intellectual Property Research Associates found another rule of thumb royalty rate:

For unknown reasons, one of the most popular royalty rates is $5 \%$ of sales. .... It shows up in a lot of different industries. It is associated with embryonic technology and mature trademarks. It has been found in the food, industrial equipment, electronics, construction and medical device industries. Forget profits, capital investment, earnings growth, operating expenses, investment risk and even development costs. Somehow $5 \%$ of sales prevails. Don't be fooled. It's not a magic bullet answer. ${ }^{26}$

Even the IPRA study did not examine the use of heuristic licensing rates other than to mention that the $5 \%$ of sales regime was found in unrelated industries.

25. Robert Goldscheider, Measuring Damages in U.S. Patent Litigation, 5 J. PROPRIETARY RTS. No. 5, at 2, 6-7 (1993).

26. IntelleCtUAl PROP. ReSEARCH Assocs., supra note 24, at 17. 
A third rule of thumb is the so-called industry norm that relies on the potentially faulty assumption that the negotiators of the earlier licenses in the industry had correctly considered and interpreted the myriad of factors affecting royalty rates. ${ }^{27}$ All of the prior mistakes made are passed along "as silly sheep leap over a vacuum, because their leader originally leaped there when a stick was held." 28

Each of these rules of thumb has been criticized $^{29}$ and some have even been shown to be suboptimal, ${ }^{30}$ but over time they have become entrenched as industry standards without necessarily reflecting the actual value of the intellectual asset rights being transferred. Both the 25 percent of profits and 5 percent of sales methods are obvious oversimplifications and do not take into account variations in industry and relative contributions to profit by different types of intellectual assets.

Worse yet, in some instances the licensor may end up "leaving money on the table" by not extracting value comparable to the average contribution to profit of intellectual property and intellectual assets for the industry as a whole (i.e., companies that exploit their intellectual assets internally are generating a higher rate of return than the rate earned by a rule of thumb royalty). ${ }^{31}$ One such example may be Handspring's license of the Palm operating system. Some analysts have indicated that Palm receives as little as $\$ 8$ per unit (or approximately 5 percent of the average price) of the various models of Handspring's Visor. ${ }^{32}$ By comparison, Palm generates a gross profit margin of 40 percent on sales of its own devices, a large portion of which can be allocated to profits due to intellectual assets. ${ }^{33}$ 184.

27. See SMITH \& PARR, supra note 10, at 368; PARR \& SUlLIVAN, supra note 10 , at

28. Herman Melville, Moby Dick 330 (Heritage Press 1956) (1851), quoted in Gordon V. SMith \& RUSSEll L. PARR, VALUATION OF INTELlectual PROPERTY AND INTANGIBLE ASSETS 377(2d ed. 1994)).

29. See, e.g., SMITH \& PARR, supra note 10; PARR \& SUllivan, supra note 10; Stiroh \& Rapp, supra note 10; Toikka, supra note 10.

30. See Gavin Clarkson \& Jasjit Singh, Optimal Structures in Contingent Licensing Contracts (2001) (unpublished manuscript, on file with author) (developing a theoretical proof demonstrating that, all else being equal, a percentage of revenue regime is superior to a percentage of profits regime).

31. Similar problems also exist for the licensee, although they are not the main focus of this article. It is possible for a rule of thumb license to place a licensee in a worse economic position than if it had done nothing at all. For a more detailed examination, see Clarkson \& ApPlegate, supra note 12. See also SMith \& PARR, supra note 10, at 372-78.

32. See Mark Gimein, Palm and Handspring Go Hand to Hand, ForTune, Sept. 18, 2000, at 319, available at 2000 WL 24218220.

33. See id. 
Unfortunately, courts have not been immune to application of these rules of thumb, particularly the 25 Percent Rule. ${ }^{34}$ Courts have been induced to apply rules of thumb such as the 25 Percent Rule in part because expert witnesses, such as Mr. Goldscheider, are often the strongest advocates for these heuristics. In Podd v. Commissioner of Internal Revenue ${ }^{35}$ the judge noted that in

a previous case before a Federal District Court in

Texas, Mr. Goldscheider offered expert testimony on the subject of what a reasonable royalty would be and the judge in that case commented that Mr. Goldscheider's credibility was adversely affected due to his appearance as an advocate rather than a detached expert. ${ }^{36}$

The advocacy of expert witnesses, however, cannot be the only explanation for the use of royalty rates based on rules of thumb. There must be other explanations.

\section{Possible EXPLANATIONS}

In order to look for ways to improve the marketplace for intellectual asset transactions, it is first necessary to examine possible explanations for how the present situation arose and why it has not corrected itself on its own. Economic theory suggests that the necessary information is too costly to acquire (i.e., difficult to obtain or not available at all), resulting in only a small number of intellectual asset transactions based on rigorous quantitative analysis, with the remainder covered by rules of thumb. Economic theory also suggests possible reasons why organizations internalize innovation and thus why licensing is not more widespread. Organizational behavior theory suggests that some forms of bounded rationality or heuristic usage, as well as organizational inertia, are responsible for the continued use of these rules of thumb. The answer probably lies somewhere in the middle.

\section{A. Economic Perspective}

34. See, e.g., Paper Converting Mach. Co. v. Magna-Graphics Corp., 745 F.2d 11, 21-22 (Fed. Cir. 1984); Polaroid Corp. v. Eastman Kodak Co., 16 U.S.P.Q. 2d 1481, 1535 (D. Mass. 1990); Syntex Inc. v. Paragon Optical Inc., 7 U.S.P.Q. 2d 1001, 1027 (D. Ariz. 1987); Tektronix, Inc. v. United States, 552 F.2d 343, 350 (Ct. Cl. 1977).

35. 75 T.C.M. $(\mathrm{CCH}) 2575$ (T.C. 1998).

36. Id. at 2588 n.9 (citing Kerwit Med. Prods., Inc. v. N \& H Instruments, Inc., 224 U.S.P.Q. 679, 691 n.6 (N.D. Tex. 1984)). 
The economic perspective contributes at least three concepts that are helpful in understanding the present situation in intellectual asset transactions. First, the property rights view of the firm is a good starting point for examining the arena of intellectual assets themselves. Second, certain economic explanations for why firms organize are helpful in understanding why firms internalize innovative activity rather than licensing innovations from outside. The third set of ideas, transaction cost theory, lends the most insight into why rules of thumb are used rather than quantitative methods for determining licensing rates in intellectual asset transactions.

Information regarding the value of intellectual assets is expensive and has historically been difficult, if not impossible, to obtain.

The economic view of the firm as a collection of property rights has particular relevance in the arena of intellectual asset transactions. This approach is complementary to the transaction cost economic theories of Coase and Williamson, but it focuses on non-human assets, particularly in contractual relationships. ${ }^{37}$ The basic premise for this view is that the right to control the usage of an asset "resides with the owner of the asset. Ownership of an asset goes together with the possession of residual rights of control over that asset, that is, the owner has the right to use the asset any way that is not inconsistent with a prior contract, a custom, or any law." ${ }^{38}$ Furthermore, the property rights view of the firm specifically includes intellectual assets such as patents and copyrights. ${ }^{39}$ The resulting theory is that in "a world of transaction costs and incomplete contracts, ex-post residual rights of control are important because, through their influence on asset usage, they affect ex-post bargaining power and the division of ex-post surplus in a relationship." ${ }^{\prime 4}$ It is that division of ex post surplus from intellectual assets transactions that is of interest.

Economic theory has also contributed insight into why technology licensing has historically been somewhat rare relative to the level of innovation. Arrow asserts that "organizations are a means of achieving the benefits of collective action in situations in which the price system fails." ${ }^{41}$ Since, in the past, there has not been much of a marketplace for intellectual asset transactions, the best way for an

37. See Oliver Hart, An Economist's Perspective on the Theory of the Firm, in ORGANIZATION THEORY 154, 160 (Oliver E. Williamson ed., 1995); see also Sanford J. Grossman \& Oliver D. Hart, The Costs and Benefits of Ownership: A Theory of Vertical and Lateral Integration, 94 J. POL. ECON. 694 (1986).

38. Hart, supra note 37 , at 160.

39. See id. at 161.

40. Id.

41. Kenneth J. Arrow, The Limits of Organization 33 (1974). 
organization to obtain intellectual assets was to create them internally rather than try to license them from another organization. This premise is bolstered by the fact that intellectual asset transactions are not entirely understood by the average manager, in part because they are legal in nature. Williamson's model of the conditions under which markets tend to give way to organizations adds the idea that "under certain environmental conditions, ... an individual's cognitive capacities are insufficient. It is the coupling of cognitive limitations with high levels of uncertainty and complexity that encourage individuals to move the affected transactions out of markets and into organizations." ${ }^{42}$ Such reasoning clearly relates to Simon's concept of bounded rationality and Kahneman \& Tversky's concept of heuristics, which are discussed in the next section.

Although the relatively low number of intellectual assets transactions as compared to the level of innovation is consistent with economic theory's view of the firm, the question of why still remains. What causes the high levels of complexity and uncertainty, resulting in such a small marketplace for intellectual asset transactions? Can this marketplace ever be expanded and fully realized, since determining the optimal way to divide the ex post surplus from an intellectual asset transaction requires a great deal of information about the transaction's environment?

One source of answers is transaction cost economics, particularly its focus on the cost of obtaining information. This theory, based on work done by Coase and later by Williamson, "shifts attention from technology and production costs to transaction costs-the costs associated with reaching and policing agreements about the exchange of goods and services between persons or across boundaries. .... These costs range from those of obtaining information, ... negotiating agreements, policing agreements, to settling disputes." ${ }^{43}$ Whereas "[s]imple market transactions work well as a framework for spot contracts, .... [t] hey fare less well when the transactions involve future values." 44 Since most intellectual asset transactions are licenses for future royalty payments, it becomes easier to understand

42. W. RICHARD SCOTT, ORGANIZATIONS: RATIONAL, NATURAL, AND OPEN SYSTEMS 156 (4th ed. 1998) (citing OLIVER E. WILLIAMSON, MARKETS AND HIERARCHIES: ANALYSIS AND ANTITRUST IMPLICATIONS (1975)).

43. SCOTT, supra note 42, at 155 (citing Ronald H. Coase, The Nature of the Firm, 4 ECONOMICA 386 (1937)); see also Oliver E. Williamson, THE ECONOMIC InSTITUTIONS OF CAPITALISM (1985); OliVER E. WILlIAMSON, MARKETS AND HIERARCHIES: ANALYSIS AND ANTITRUST IMPLICATIONS (1975); OLIVER E. WILLIAMSON, TRANSACTION COST ECONOMICS AND ORGANIZATIONAL THEORY, in THE HANDBOOK OF ECONOMIC SOCIOLOGY 77 (Neil J. Smelser \& Richard Swedberg eds., 1994).

44. SCOTT, supra note 42 , at $155-56$. 
the historically small level of market transactions for intellectual assets.

Similarly, because licensing negotiations ultimately require decisions to agree when there is insufficient information to comfortably support those decisions, the number of such transactions will be small. As Scott points out, "bargaining and negotiation are complex activities, requiring knowledge of one's own interests and priorities, those of others, information about the current and likely future states of affairs, knowledge of rule systems and norms governing agreements, and related matters. ${ }^{.45}$ Arrow notes that the gathering of information is also essential to arriving at a decision. ${ }^{46}$ Thus, absent sufficient information, such negotiations are unlikely to conclude satisfactorily, if they take place at all, without resorting to a rule of thumb which requires less information than a quantitative analysis.

But what exactly is the information that is so difficult to obtain? It is the fair market value ("FMV") of the various rights to the intellectual assets involved in the transaction. In general, FMV "is the price at which an asset would trade between two rational individuals, each in command of all of the information necessary to value the asset and neither under any pressure to trade. ${ }^{, 47}$ Relating this concept to royalty rates, courts have often used a variation of FMV in the form of a "willing buyer and willing seller" rule in an attempt to calculate patent infringement damages. ${ }^{48}$ The difficulties lie in the fact that intellectual asset valuations are not easy to obtain, unlike valuations of real estate, where market comparables give a fairly close approximation of the FMV of a piece of land.

In general, the market approach "measures the present value of future benefits by obtaining a consensus of what others in the marketplace have judged it to be. There are two requisites: an active, public market and an exchange of comparable properties." ${ }^{49}$ Unfortunately, these two requisites rarely exist for a sufficiently strong estimate of value of intellectual assets; it is often difficult, if not impossible, to find even one market comparable transaction that can be used to assist in valuing another transaction. The example

45. Id. at 200 (citing BAZERMAN \& NeALE, supra note 23).

46. SCOTT, supra note 42, at 160 (citing ARROW, supra note 41, at 69).

47. Robert C. Higgins, ANALYSIS FOR Financial MANAgEment 318 (5th ed. 1998). "[T]he FMV of a business is the higher of its liquidation value and its goingconcern value," where going-concern value is "the present worth of expected future cash flows generated by a business." Id. This concept is similar to the income approach to valuation, discussed infra text accompanying note 54 .

48. Georgia-Pacific Corp. v. United States Plywood Corp., 318 F. Supp. 1116, 1121 (S.D.N.Y. 1970).

49. SMITH \& PARR, supra note 10 , at 160. 
closest to a public market is the Virtual Socket Alliance ("VSA"), a consortium of 125 semiconductor companies that has created a private system for exchanging intellectual assets related to the electronics industry. ${ }^{50}$ Along with the VSA, other initiatives such as PricewaterhouseCoopers' Intellectual Property Exchange ("IPEX") $)^{51}$ are attempting to create public markets for intellectual assets, but these efforts are in the early stages of development.

Cost basis valuations are not very helpful either. The cost approach attempts to measure the future benefits of the license of a technology by quantifying the investment that would be required to replace the future service capability of the technology, frequently referred to as replacement cost. ${ }^{52}$ Often the cost approach is a very conservative if not a poor method of valuation because a company can invest very little in technology and invent something with value that greatly exceeds cost. One such example of a breakthrough technology is Post-It Notes, which 3M introduced in 1980. This simple invention cost $3 \mathrm{M}$ very little to develop ${ }^{53}$ but the company has reaped huge profits from an entire line of products based on the original invention.

The third method, the income approach, is based on the premise that the FMV of an intellectual asset-or any asset for that matter - can be expressed as the present value of the anticipated stream of economic benefits that can be secured by ownership of the asset. $^{54}$ In essence, this approach examines the income-producing capability of an intellectual asset to determine its value. The three main questions answered by the income approach are:

(1) What is the income stream that will be generated over time by the intellectual asset?

(2) How long will that stream last?

(3) What is the likelihood that the forecasted income stream will materialize?

50. See generally Joseph Costello, Overcoming the Behemoth: The Urgent Need for a Private Legal System in Electronics, in CAPITAL FOR OUR TIME: THE ECONOMIC, Legal, and Management Challenges of Intellectual Capital 51 (Nicholas Imparato ed., 1999).

51. The IPEX is available at http://www.ipex.net. Other exchanges include Yet2.com (http://www.yet2.com), the Patent and Licensing Exchange (http://www.pl-x.com), and the Intellectual Property Technology Exchange (http://www.techex.com).

52. See SMITH \& PARR, supra note 10 , at 164.

53. See Eric N. Berg, Now "Intrapreneurship" Is Hot, N.Y. TimES, Apr. 4, 1985, at D1 (describing the development of Post-It Notes).

54. See SMITH \& PARR, supra note 10, at 257. 
In addition to the fact that the income approach is not readily understood by managers when applied to intellectual assets, it is clear from these three questions that the income approach is rife with uncertainty and speculation absent some form of robust metrics. Thus the view of the environment for intellectual asset transactions is one in which these transactions are moved out of markets and into organizations,${ }^{55}$ and rules of thumb are used for whatever market transactions remain.

At this point, it would seem appropriate to merge the economic perspective with the organizational behavior perspective, particularly regarding the concepts of bounded rationality and heuristics. The organizational behavior perspective on bounded rationality and heuristics provide superior insight into the present status of intellectual asset transactions than does the economic perspective on bounded rationality. ${ }^{56}$

\section{B. Organizational Behavior Perspective}

Since managers normally have neither sufficient information nor quantitative metrics to make fully informed decisions in intellectual asset negotiations, their use of a rule of thumb in the few transactions that do take place in the market seems to be evidence of "satisficing," or settling for a method that is good enough, rather than expending additional effort to find a superior approach. Simon's definition of bounded rationality describes this situation almost exactly:

The capacity of the human mind for formulating and solving complex problems is very small compared with the size of the problems whose solution is required for objectively rational behavior in the real world. ${ }^{57}$

Simon continued, stating that

[t]he key to simplification of the choice process ... is the replacement of the goal of maximizing with the goal of satisficing, or finding a course of action that is 'good enough.' ... [T] his substitution is an

55. See supra note 42 and accompanying text.

56. See Oliver E. Williamson, Chester Barnard and the Incipient Science of Organization, in ORGANIZATION THEORY 172, 179 (Oliver E. Williamson ed., expanded ed. 1995) (summarizing the economic perspective on bounded rationality as "all complex contracts are unavoidably incomplete.").

57. Herbert A. Simon, Models of Man: Social and Rational 198 (1957). 
essential step in the application of the principle of bounded rationality. ${ }^{58}$

Simon provided this concept as an alternative to "the "economic man' motivated by self-interest and completely informed about all available alternatives ... [and who] is willing to settle for an adequate solution in contrast with an optimal one." 59

Fifteen years after Simon's original publication of his theories of bounded rationality, Kahneman and Tversky extended the theory by introducing heuristics and explaining the potential pitfalls of their use.

[P]eople rely on a limited number of heuristic principles which reduce the complex tasks of assessing probabilities and predicting values to simpler judgmental operations. In general, these heuristics are quite useful, but sometimes they lead to severe and systematic errors. ${ }^{60}$

Availability, ${ }^{61}$ Anchoring and Adjustment,${ }^{62}$ and Representativeness ${ }^{63}$ are the heuristics elucidated by Kahneman and Tversky that Bazerman identifies as potentially impacting negotiations. ${ }^{64}$ These heuristics should be considered when evaluating heuristic behavior in licensing.

Such concepts explain the use of rules of thumb in intellectual asset transactions. DiMaggio and Powell have credited March and Simon with the observation that "organizational behavior, particularly decision making, involves rule following more than [quantitative] calculation." ${ }^{65}$ March and Simon have also been credited with the idea that "organizations face environments of varying complexity, that they must adjust their internal decision-making apparatus to take

58. Id., at 204-05 (emphasis in original).

59. SCOTT, supra note 42 , at 50.

60. Daniel Kahneman \& Amos Tversky, Judgment Under Uncertainty: Heuristics and Biases, 185 SCIENCE 1124, 1124 (1974).

61. See BAZERMAN, supra note 23, at 6 ("Managers assess the frequency, probability, or likely causes of an event by the degree to which instances or occurrences of that event are readily 'available' in memory.").

62. See id. at 7("Managers make assessments by starting from an initial value and adjusting to yield a final decision. .... In ambiguous situations, a trivial factor can have a profound effect on our decision if it serves as a starting point from which we make adjustments.").

63. See id. ("Managers assess the likelihood of an event's occurrence by the similarity of that occurrence to their stereotypes of similar occurrences.").

64. See BAZERman \& NeAle, supra note 23; BAZERMAn, supra note 23.

65. Walter W. Powell \& PaUl J. DiMaggio, The NeW Institutionalism in ORGANIZATIONAL ANALYSIS 19 (1991). 
these variations into account, and that some environments pose levels of complexity that the organizations cannot manage unless they impose simplifying restrictions on the information processed." Similarly, Thompson elucidated the concept of bounded rationality arising from organizational structure: "structure is a fundamental vehicle by which organizations achieve bounded rationality.' The specification of positions, role definitions, procedural rules and regulations [as] inputs that guide decision making - all function to canalize behavior in the service of predetermined goals." 67 According to Scott, bounded rationality can beceome part of the organizational structure rather than reemain a part of the individuals themselves as "rules that assure participants will behave in ways calculated to achieve desired objectives." 68

Not only does the organizational behavior perspective shed light on why a single firm might "satisfice" by choosing a rule of thumb for valuing an intellectual asset transaction, it also helps to explain why such heuristics become commonplace through organizational conformity. Actors in the current marketplace for intellectual asset transactions use these rules of thumb because the lack of preferable alternatives entrench them as the only viable methods of choice. "We do it this way because this is the way we have always done it, and this is how everyone expects it to be done in the industry." Scott elaborates on this concept in his discussion of structural conformity: "Sometimes environmental actors impose very specific structural requirements on organizations as a condition for acceptance and support. Organizations are required to adopt specific structural elements [such as rules of thumb] in order to merit approval." 69 Similarly, DiMaggio and Powell point out that "organizations confronting high levels of uncertainty often borrow structural forms, sometimes by consciously modeling a successful form." 70 "Groupthink" ${ }^{, 71}$ may also be a factor in highly cohesive groups. ${ }^{72}$ It is

66. SCOTT, supra note 42, at 110-11.

67. Id. at 53-54 (quoting JAMES D. THOMPSON, ORGANIZATIONS IN ACTION 54 (1967)).

68. Id. at 54 .

69. Id. at 213.

70. Id. at 54 (citing Paul J. DiMaggio \& Walter W. Powell, The Iron Cage Revisited: Institutional Isomorphism and Collective Rationality in Organizational Fields, AM. SoC. REV., Apr. 1983, at 147, 152).

71. See generally Irving L. Janis, Groupthink, in READINGS IN MANAGERIAL PsYCHOLOGY 439 (Harold J. Leavitt et al. eds., 1971).

72. See BAZERMAN, supra note 23 , at 151-52 (recognizing that the Kahneman and Tversky heuristics can also play a role with groups) 
thus possible that rational participants might be persuaded to adopt heuristic positions because of group pressure. ${ }^{73}$

In Scott's discussion of procedural conformity, he places some blame for the need to satisfice rather than optimize in intellectual asset transactions on lawyers: "Even when the demands being enforced are primarily technical, the requirements are often couched in procedural language - the language of lawyers - rather than in language that attempts to specify [efficient] outcomes." ${ }^{74} \mathrm{He}$ also identifies other criticisms of lawyers, noting that "these procedures readily become disconnected from outcomes, creating legalistic mazes and bureaucratic rituals rather than providing a framework to support rational decision making." 75 Finally, Scott notes that for decisions made near the top of an organization, including intellectual asset transactions, "as long as [the value premises that govern decision making] are specific enough to provide clear criteria for choice, these premises can support a 'rational' structure no matter how monstrous or perverted their content." ${ }^{, 76}$ It is probably a bit harsh to describe the rules of thumb used in intellectual asset transactions as "monstrous or perverted"; nevertheless, there must be ways to improve the situation to make these transactions both more efficient and more numerous.

\section{Possible IMPROVEMENTS}

\section{A. Theoretical Basis}

In addition to shedding light on the present state of the market for intellectual asset transactions, these perspectives, particularly the organizational behavior perspective, provide guidance on how these transactions might be made both more efficient and more numerous. Oddly enough, the basis for these improvements can be found in the scientific management approach developed by Frederick Taylor in the early 1900s. ${ }^{77}$ Citing Taylor's work, Scott defines "performance programs" as

73. See generally S.E. Asch, Effects of Group Pressure upon the Modification and Distortion of Judgements, in BASIC STUdIES IN SOCIAL Psychology 393 (Harold M. Proshansky \& Bernard Seidenberg eds., 1965).

74. SCOTT, supra note 42 , at 215.

75. Id. at 215 (citing EUGENE BARDACH \& ROBERT A. KAGAN, GOING BY THE BoOK: The Problem of Regulatory UnReasonableness (1982)).

76. Id. at 54 .

77. See generally Frederick W. TAYlor, The Principles OF SCIENTIFIC MANAGEMENT (1911). 
sets of activities that are performed in a regular and predictable way to carry out the work of the organization, [and according to rational systems theory,] these programs can and should be rationalized: engineers and technical staff must analyze the work requirements and design the necessary operations so as to minimize time and resource use. ${ }^{78}$

For organizations dealing with intellectual assets, the valuation metrics for intellectual assets could be considered performance programs.

If Taylor's principles apply to intellectual assets, it must be possible to analyze intellectual asset transactions scientifically in order to discover those procedures that would produce the maximum efficiency while still minimizing the input of information and the amount of uncertainty. Taylor would probably seek to replace rules of thumb with analytical, scientific procedures. According to Taylor, the decision maker "under scientific management is governed by rules and laws which have been developed through hundreds of experiments." 79 In the arena of intellectual asset transactions, however, it may not be necessary to conduct experiments if the information can be obtained from publicly available data.

Suppose that the necessary information is available to optimize intellectual asset transactions, but the marketplace is not aware of it. If the marketplace could be made aware of the information and given the metrics to utilize it, then it is likely that intellectual asset transactions would become more efficient and more numerous. Many elements of organizational behavior theory support this conclusion. According to Scott, organizations "support participants in the decisions they must make . . by providing them with the necessary means to handle them: resources, information, equipment." 80 Systems theory states that "the setting of goals is based on information received from the environment so that favorable exchanges between the environment and organization can occur." ${ }^{181}$ Thus, the organization must be convinced that the information is available if it is to view increased efficiency in intellectual asset transactions as a reachable goal.

78. SCOTT, supra note 42, at 250 (citing TAYLOR, supra note 77; FREDERICK W. TAYLOR, SCIENTIFIC MANAGEMENT 189 (1947)).

79. FREDERICK W. TAYLOR, SCIENTIFIC MANAGEMENT 189 (1947).

80. SCOTT, supra note 42 , at 51-52.

81. Id. at 86 . 
Intellectual asset transactions will always, by nature, be complex and subject to uncertainty and risk. Therefore, greater availability of information will be critical to any increase in the efficiency or number of these transactions. According to Galbraith, "the greater the task uncertainty, the greater the amount of information that must be processed among decision makers during task execution in order to achieve a given level of performance." 82 A mere increase in information is insufficient, however, to overcome the problems of bounded rationality.

Metrics that facilitate the processing of the information are also required. According to transaction cost theory, "as exchanges become more complex and uncertain - because the environment is not stable or predictable ...-various kinds of external controls and supports must be devised to aid the exchanges-that is, to reduce the transaction costs." $\$ 3$ This conclusion is also reinforced when one considers March's concept of attention structure. If the organization is swamped with information, it will not be able to process the information adequately in order to optimize the intellectual asset transaction. According to March,

Time and capabilities for attention are limited. Not everything can be attended to at once. Too many signals are received. Too many things are relevant to a decision. Because of these limitations, theories of decision making are often better described as theories of attention or search than as theories of choice. They are concerned with the way in which scarce attention is allocated. ${ }^{84}$

However, if the organization has sufficient metrics or information processing systems, as defined by Pfeffer and Salancik, ${ }^{85}$ then the organization can focus its scarce attention on optimizing the intellectual asset transaction because the "information systems are designed and created to provide the information that the decision maker requires." $\$ 6$

82. JAY R. GALBRAITH, ORGANIZATION DESIGN 36 (1977).

83. SCOTT, supra note 42, at 112 (discussing the work of Oliver Williamson).

84. James G. MARCh, A PRIMER ON DECISION MAKING: How DeCisions Happen 10 (1994).

85. See JefFrey Pfeffer \& Gerald R. Salancik, The External Control of ORganizations: A Resource DEPENDENCE PERSPECTIVE 74 (1978).

86. Id. at 75 . 


\section{B. Proposed Methodology}

After exploring economic and behavioral concepts in order to explain the current state of affairs in the marketplace for intellectual asset transactions, it is clear that those same perspectives also provide the impetus for increasing both transaction efficiency and numerosity by obtaining additional information and by providing metrics to process that information. As mentioned previously, ${ }^{87}$ one potential quantitative approach to determining asking price involves the use of publicly available industry information together with basic financial formulas to determine the contribution to profit of intellectual assets. Expressed as percentage of sales, this result can be used as a starting point for royalty rate negotiations or as a "reality check" for royalty rates determined by other means.

This proposed method follows from the premise that the licensor should be able to extract from the licensee a royalty stream that is comparable to its own return on intellectual property and intellectual assets ("IPIA"). ${ }^{88}$ Alternatively, a licensor can look to its industry for the average return on IPIA. Since returns on intellectual assets are not normally reported in company financial statements, it is necessary to derive them from whatever data is available. An industry average contribution to profit from intellectual property and intellectual assets ("CPIPIA") ${ }^{89}$ can be derived from annual reports and other publicly available information. Before a measure for intellectual assets can be derived, however, the contribution to profit of intangible assets ("CPIA"), which includes intellectual assets, must be derived. Once CPIA is determined, the calculation of CPIPIA is straightforward.

For those not familiar with corporate finance concepts, the CPIA metric is, in essence, an expression of the percentage of a company's profits that are due to its intangible assets. Intangible assets are assets other than monetary assets (i.e., cash and liquid securities on hand) and tangible assets (i.e., property, plant and equipment). ${ }^{90}$ CPIPIA is derived in a given industry by subtracting the average CPIA value for distributors from the CPIA value for a given manufacturer or a

87. See supra text accompanying notes $10-11$.

88. See supra note 17.

89. The terms CPIA (contribution to profit of intangible assets), IPIA (intellectual property and intellectual assets), and CPIPIA (contribution to profit of IPIA) are new terms contrived for this discussion of intellectual asset valuation. The author accepts full blame (or credit) for their relative utility in this analysis.

90. A somewhat similar measure, the Knowledge Capital Scoreboard developed by Professor Baruch Lev of New York University, identifies the total intangible asset value for several companies, but does not readily generate proxies for royalty rates. See Baruch Lev \& S.L. Mintz, Seeing is Believing: A Better Approach to Estimating Knowledge Capital, CFO Magazine, Feb. 1999, at 29, available at 1999 WL 8850771. 
portfolio of manufacturers. For those more familiar with corporate finance, the remainder of this section describes the derivation of CPIA and the resulting CPIPIA.

\section{Contribution to Profit of Intangible Assets - CPIA}

This first metric is based on the existence of two formulations of the Weighted Average Cost of Capital ("WACC"). The traditional formulation of $\mathrm{WACC}^{91}$ is

$$
W A C C=E\left(R_{i}\right)+D\left(R_{i}\right)=R_{f}+\beta \times E\left(R_{p}\right)+i \times(1-t)
$$

where

$E\left(R_{i}\right): \quad$ expected rate of return for equity investors

$D\left(R_{i}\right)$ : expected rate of return for debt investors

$R_{f}: \quad$ risk free rate of return

$\beta$ : $\quad$ beta or systematic risk

$E\left(R_{p}\right):$ expected risk premium

$i: \quad$ interest rate on debt

$t$ : effective federal and state tax rate

The theoretical underpinnings of WACC are based on the idea that "a company's cost of capital is the cost of the individual sources of capital, weighted according to their importance in the firm's capital structure. ${ }^{92}$ WACC can thus be broken down into its relative components, and be represented as a weighted average of the required return from monetary, tangible, and intangible assets: ${ }^{93}$

$W A C C=\frac{V_{m}}{V_{b e v}} R_{m}+\frac{V_{t}}{V_{b e v}} R_{t}+\frac{V_{i}}{V_{b e v}} R_{i}$

$R_{m}: \quad$ return on monetary assets

$R_{i}: \quad$ return on tangible assets

$R_{i}$ : $\quad$ return on intangible assets

$V_{m}: \quad$ fair market value of the monetary assets

$V_{t}: \quad$ fair market value of the tangible assets

91. See generally Higgins, supra note 47 , at $277-78$ (providing an excellent discussion of the derivation of WACC).

92. Id. at 278 .

93. SMITH \& PARR, supra note 10 , at 360. 
$V_{i}: \quad$ fair market value of the intangible assets

$V_{b e v}:$ the fair market value of the business enterprise (the sum of $V_{m}, \quad V_{t}$, and $V_{i}$ ).

Solving for $\left(V_{i} / V_{b e v}\right) \times R_{i}$ (or $\left.R_{i w}\right)$, the weighted rate of return on intangible assets, ${ }^{94}$ results in:

$$
\frac{V_{i}}{V_{b e v}} R_{i}=W A C C-\frac{V_{m}}{V_{b e v}} R_{m}-\frac{V_{t}}{V_{b e v}} R_{t}=R_{i w}
$$

and the unweighted rate of return on intangible assets, $R_{i}$, is:

$$
R_{i}=\frac{W A C C-\frac{V_{m}}{V_{b e v}} R_{m}-\frac{V_{t}}{V_{b e v}} R_{t}}{\frac{V_{i}}{V_{b e v}}}
$$

Using the 3-month T-Bill for $R_{m}$ and the 10-year T-Bond for $R_{t},{ }^{95}$ one can calculate the respective weighted returns for monetary and tangible assets using data from a company's balance sheets and income statements. ${ }^{96}$ As shown above, subtracting the weighted rate of return on monetary assets and tangible assets from WACC yields the weighted rate of return for intangible assets.

To obtain the weighted return on intangibles as a percentage of the total cost of capital, $R_{i w}$ is divided by the previously derived WACC value. Multiplying this value by Debt Free Net Income ("DFNI") ${ }^{97}$ results in the contribution to profit by intangible assets expressed in dollar terms.

$$
D F N I=N I+\text { InterestExpense }(1-\operatorname{tax})
$$

Dividing that value by sales gives us CPIA expressed as a percentage.

94. Note that Lev's methodology for deriving knowledge-based earnings is based on a very similar residual calculation. See Lev \& Mintz, supra note 90.

95. $C f$. Richard A. Brealey \& Stewart C. Myers, Principles of Corporate FINANCE 548 \& n. 8 (6th ed. 2000) (suggesting use of T-Bill and T-Bond rates to represent return on monetary and tangible assets respectively).

96. The mechanics of these calculations are fairly straightforward. From the balance sheet of a given firm, $V_{m}$ is the total Working Capital, $V_{t}$ is the total Fixed Assets, and $V_{b e v}$ is the total Market Cap of the firm plus the short term and long term debt.

$V_{i}=V_{b e v}-V_{m}-V_{t}$.

97. DFNI is roughly equivalent to EBIAT, Earnings Before Interest but After Taxes. 


$$
\text { CPIA }=\frac{\frac{R_{i w}}{W A C C} D F N I}{\text { Sales }}
$$

To recap, $\left(R_{i w} / W A C C\right) \times D F N I$ expresses the portion of a firm's profits that are due to intangible assets. Contingent royalties, however, are properly expressed as a percentage of sales. Dividing $\left(R_{i w} / W A C C\right) \times D F N I$ by sales results in such a percentage. This calculation can be repeated for all of the companies in an industry to arrive at an average CPIA.

\section{Contribution to Profit of Intellectual Assets - CPIPIA}

Because CPIA still includes the contribution to profit of intangible assets other than intellectual property and intellectual assets, these non-IPIA elements must be filtered out in order to arrive at a CPIPIA that can then be used as the licensor's starting point for royalty rate negotiations. In a given industry, some companies might have strong IPIA portfolios while other, equally well-run companies may lack IPIA. ${ }^{98}$ Subtracting an industry average for CPIA for companies without IPIA from the CPIA value for a company with an IPIA portfolio, or an industry average for companies with IPIA portfolios, yields a value for CPIPIA, the contribution to profit of both intellectual property and intellectual assets for a given company or industry.

\section{Empirical Analysis and Validation of Metrics}

Although not an exact measure of a company's intellectual asset value, CPIPIA seems to be a good industry-based approximation. CPIPIA is an appropriate starting point for royalty rate negotations by virtue of its basis in a WACC calculation that is specific to the company in question. Since the CPIPIA metric is based on hypothesized behavior of CPIA, that behavior should be demonstrated empirically before any further exploration of CPIPIA is warranted.

98. For example, pharmaceutical companies such as Amerisource, McKesson, and Bergen Brunswig do not engage in substantial IPIA creation, whereas companies such as Abbott Laboratories, Bristol-Myers Squibb, and Schering-Plough have substantial IPIA portfolios. Similar dichotomies have been observed in the electronics, computer hardware, computer software, chemical, cosmetics, and food products industries. See, e.g., PARR \& SUlLIVAN, supra note 10, at 232 (computer hardware); SMITH \& PARR, supra note 10 , at $228-38$ (pharmaceuticals and food products). 
The main underlying assumption in the CPIA metric is that CPIA values will be higher for companies with large intangible asset portfolios and lower for companies with few or no intangible assets. To verify this assumption, it is necessary to examine the relationship among CPIA, R\&D expenditures, and manufacturer/distributor classification in a single industry. Given that many pharmaceutical companies engage in significant $R \& D$ to increase their portfolios of intangible assets, a positive correlationbetween $R \& D$ expenditures and CPIA values should exist for companies in this industry.

H1: As a firm's R\&D expenditures increase as a percentage of sales, so will its contribution to profit of intangible assets increase as a percentage of sales.

The pharmaceutical industry is divided into two Standard Industry Classification ("SIC") codes. ${ }^{99}$ SIC code 2834 primarily contains manufacturers, and SIC code 5122 primarily contains distributors. ${ }^{100}$ Manufacturers generally engage in more $\mathrm{R} \& \mathrm{D}$ relative to sales volume than do distributors. Thus, if CPIA behaves as expected, then firms in the 5122 classification will have lower CPIA values than those classified in 2834 .

$\mathrm{H} 2$ : Classification as a manufacturer is associated with having a higher CPIA value than classification as a distributor.

Using Compustat ${ }^{101}$ financial statement data and Datastream ${ }^{102}$ bond rate data, a value for CPIA can be calculated for each pharmaceutical company. ${ }^{103}$ Then using Compustat R\&D expenditure data, the following Ordinary Least Squares model can be evaluated:

$$
C P I A=\beta_{0}+\beta_{1} \times R D S A L E S+\beta_{2} \times S I C
$$

99. SIC codes are promulgated by the National Technical Information Service. See generally Nat'l Tech. Info. Serv., NTIS Web Site Home Page, at http://www.ntis.gov/ (last visited Apr. 25, 2001).

100. As shown in the Appendix, however, some of the companies in the 5122 classification do engage in some level of R\&D expenditure.

101. See Standard \& Poor, Institutional Market Services, at http://www.compustat.com/ (last visited Apr. 25, 2001).

102. See Primark Corp., Products, at http://www.datastream.com/product/has/ index.htm (last visited Apr. 25, 2001).

103. Only companies with positive DFNI and for which revenues were greater than DFNI were included. The resulting sample included 58 firms, which are listed in the Appendix. 
where RDSALES is R\&D expenditure expressed as a percentage of sales, and SIC is an indicator variable, 1 for manufacturers and 0 for distributors.

\section{Regression Results for CPIA, RDSALES, and SIC Classification}

\begin{tabular}{|c|c|c|c|c|c|c|c|}
\hline Source & SS & $d f$ & \multicolumn{2}{|c|}{ MS } & & $\begin{array}{l}\text { Number of obs } \\
F(2,55)\end{array}$ & 58 \\
\hline Model & .346209023 & 2 & .17 & 512 & & Prob > F & 0.0000 \\
\hline Residual & .295076552 & 55 & .00 & 028 & & R-squared & $=0.5399$ \\
\hline Total & .641285576 & 57 & .01 & 624 & & $\begin{array}{l}\text { Ad) Root MSE } \\
\text { Rode }\end{array}$ & $\begin{array}{l}=.07231 \\
=.07325\end{array}$ \\
\hline CPIA & Coef. & Std. & Err. & t & $P>|t|$ & [95\% Conf. & Interval] \\
\hline RDSALES & .5391483 & .090 & 3553 & 5.934 & 0. & .3570702 & .7212263 \\
\hline SIC & .0939723 & .027 & 3601 & 3.373 & 0.001 & .0381395 & .1498052 \\
\hline _cons & .0121287 & .024 & 155 & 0.497 & 0.621 & -.0368011 & .0610584 \\
\hline
\end{tabular}

The regression results, summarized in the table above, indicate that the regression model explains more than half of the variance in CPIA. Additionally, the results indicate both a significant $(\mathrm{p}<.001)$ positive relationship between $R \& D$ expenditures as a percentage of sales and CPIA, which confirms the first hypothesis. A significant ( $p$ $=.001$ ) positive correlation between manufacturer/distributor status and CPIA supports the second hypothesis.

With empirical support for both hypotheses, it is safe to proceed with the application of the CPIPIA metric, since it is evident that firms engaging in significant $R \& D$ or classified as manufacturers tend to have higher CPIA values than firms with low R\&D expenditures as a percentage of sales and firms classified as distributors. ${ }^{104}$

\section{Application of the CPIPIA Metric}

Thus far, this article has developed a metric for calculating CPIA from publicly available market data, has verified that firms that engage in relatively higher levels of R\&D as a percentage of sales have higher CPIA values, and has demonstrated that bifurcation of an industry into manufacturers and distributors is consistent with the hypothesized behavior of CPIA. As a result, subtracting the average CPIA value for a group of distributors from the CPIA value for a given manufacturer results in a CPIPIA value that reflects contribution to profit of intellectual assets for that manufacturer.

104. Regressing CPIA against RDSALES alone also indicated a significant $(\mathrm{p}<.001)$ relationship, but with a lower $\mathrm{r}^{2}(.4447)$. Similar indications resulted from a model with only CPIA and SIC $\left(\mathrm{p}<.001\right.$ and $\left.\mathrm{r}^{2}=.2453\right)$. 
Subtracting the average distributor CPIA from the average manufacturer CPIA results in an industry CPIPIA.

How might one use this metric in an actual licensing transaction? Two particular uses seem readily apparent. The first use is as a starting point for a royalty rate negotiation. The second use is as a "reality check" to validate a royalty rate derived through other quantitative means.

To determine CPIPIA for an average company in an industry, the starting point would be to use a set of company data, such as that presented in the Appendix, to calculate CPIA for each company. Companies would then be grouped into low CPIA (distributors) and high CPIA (manufacturers) and the average CPIA values calculated for each group. ${ }^{105}$ The distributor CPIA value would be subtracted from the manufacturer CPIA value to yield a CPIPIA value as an industry average. ${ }^{106}$ For a company-specific CPIPIA, the average distributor CPIA value would be subtracted from the CPIA value for that company. ${ }^{107}$

To use CPIPIA to validate a royalty rate generated through other means, a confidence interval for CPIPIA can be calculated to determine whether the given rate falls within that interval. ${ }^{108}$ If not, it might be worthwhile to either reexamine the methodology used to derive the royalty rate or reevaluate the business case for granting the license. ${ }^{109}$

\section{CONCLUSION}

As the knowledge economy expands, the marketplace for intellectual asset transactions will have to mature. In order to do so, the participants in the market must have a better understanding of the value of the assets involved in these transactions. Much of this author's ongoing research involves locating relevant information and

105. Note that median value is more resistant to outliers than is the mean, and thus may be a more appropriate reflection of the midpoint of the data for certain distributions.

106. The resulting average CPIPIA for the sample data provided in the Appendix is $14.4 \%$.

107. For example, the resulting CPIPIA for Merck for the sample data provided in the Appendix is $17.3 \%$.

108. The $95 \%$ confidence interval for the average CPIPIA for the sample data provided in the Appendix is between $11.6 \%$ and $17.2 \%$ Note that this confidence interval includes the $16.2 \%$ Knowledge Capital Earnings/Sales average for pharmaceuticals generated by Lev. See Lev \& Mintz, supra note 90.

109. Even if a royalty rate seems low relative to the industry average CPIPIA, there may be other strategic reasons to enter into the licensing relationship when the benefits outweigh the economic difference between the license rate and the industry average CPIPIA. 
exploring robust metrics to process that information to achieve a better understanding of the intellectual asset market. Using such quantitative metrics, intellectual asset transactions can take place in a more informed manner. Licensors can enter negotiations knowing their industry's average contribution to profit from intellectual assets that are exploited internally. They can use this average as a starting point for a royalty rate, with the range of CPIPIA across the industry defining a reaonable range of royalty rates. Alternatively, CPIPIA can be used as a "reality check" for license rates derived by other means.

On the other side of the transaction, with an appropriate set of metrics, the licensee could enter negotiations with a reasonable estimate of the range of appropriate royalty rates. ${ }^{110}$ The convergence of these two ranges defines a set of win-win licensing scenarios. If there are no win-win scenarios, the parties can then make an informed decision whether to look elsewhere for licensing possibilities. Use of metrics by both parties increases the likelihood that assets will be used so as to maximize their value.

110. Although not covered in this article, quantitative metrics can also be quite useful in determining the licensee's acceptable range of royalty rates. See generally MARTHA AmRam \& NAlin KulatilaKa, ReAl Options (1999); Timothy A. Luehrman, Strategy as a Portfolio of Real Options, HARV. BUS. ReV., Sept.-Oct. 1998, at 89; ClarKSON \& APPLEGATE, supra note 12. 


\section{APPENDIX}

\begin{tabular}{|c|c|c|c|c|c|c|c|c|}
\hline 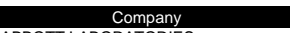 & REV & NI & DFNI & R_D & RDSALES & MKTCAP & CPIA & SIC \\
\hline DRATORIES & $1,013.46$ & 882 & $1,939.3$ & 2018 & & & & \\
\hline CREDO HEALTH I & 256.43 & 3.13 & 5.14 & $\$$ & $0.00 \%$ & 297.27 & $1.8 \%$ & \\
\hline DRN INC & 64.63 & 6.67 & 7.82 & 2.74 & & 90.92 & & \\
\hline LERGAN INC & $\$ 1,452.40$ & $\$ 188.20$ & 197.80 & 168.40 & $11.59 \%$ & $6,458.50$ & $13.6 \%$ & \\
\hline PHARMA INC -CL A & 742.18 & 39.55 & 64.24 & 40.17 & $5.41 \%$ & 910.60 & $8.2 \%$ & \\
\hline ALZA CORP & 406.30 & 92.40 & 119.52 & 26.80 & $6.60 \%$ & $2,189.02$ & $7.7 \%$ & \\
\hline AMARIN CORP PLC -SPON ADR & 11.21 & 4.37 & 5.51 & 7.43 & $66.28 \%$ & 90.32 & $49.3 \%$ & \\
\hline ABI INC & 28.30 & 5.86 & 6.10 & 1.79 & $6.31 \%$ & 73.51 & $21.2 \%$ & \\
\hline IERISOURCE HEALTH CP -C & $9,807.36$ & 67.47 & 91.28 & & $0.00 \%$ & $1,216.43$ & $0.8 \%$ & \\
\hline TRAZENECA PLC -SPON AD & $17,950.00$ & $\$ 1,143.00$ & $\$ 1,231.80$ & $\$ 2,472.00$ & $13.77 \%$ & $4,106.25$ & $.8 \%$ & \\
\hline RR LABORATORIES & 444.03 & 49.25 & 50.99 & 22.59 & $09 \%$ & 909.39 & $10.4 \%$ & \\
\hline USCH \& LOMB INC & $1,756.10$ & $\$ 444.80$ & 497.84 & 97.60 & $.56 \%$ & $3,926.70$ & $22.0 \%$ & \\
\hline RGEN BRUNSWIG CORP -CL & $21,245.54$ & 70.57 & 117.98 & - & & $1,392.39$ & $0.4 \%$ & \\
\hline NDLEY WESTE & $8,507.61$ & 38.30 & 52.36 & - & $0.00 \%$ & & $0.2 \%$ & \\
\hline OVAIL CORP & 151.79 & 62.48 & 67.97 & 33.13 & $1.83 \%$ & $5,830.87$ & $44.6 \%$ & \\
\hline ICL & 18.85 & 0.56 & 0.70 & - & & 8.60 & $3.4 \%$ & \\
\hline ISTC & $20,222.00$ & $\$ 4,167.00$ & $\$ 4,245.00$ & 43.00 & & $7,143.98$ & $20.8 \%$ & \\
\hline CARDIN & $\$ 25,033.60$ & $\$ 456.30$ & $\$ 515.94$ & $\$ 49.70$ & $\%$ & $17,563.84$ & $1.8 \%$ & \\
\hline & 423.70 & 27.13 & 32.15 & 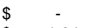 & & & & \\
\hline NC & 298.14 & 20.16 & 2.25 & 1.84 & $\%$ & 187.46 & $13.9 \%$ & \\
\hline GICAL -CLA & 10.78 & 2.42 & 2.78 & . & $\%$ & 24.84 & $18.1 \%$ & \\
\hline & 3 & 60.58 & & 3.70 & & & & \\
\hline $\mathrm{MM}$ & 41.31 & 0.27 & 0.27 & 0. & & 3.10 & $0.3 \%$ & \\
\hline SOURCES II & 815.32 & 6.36 & 9.51 & - & & 104.43 & $0 \%$ & \\
\hline & $\$$ & & & 49.7 & & & & \\
\hline Th & & 0 & 0.91 & 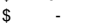 & & & $3 \%$ & \\
\hline $\mathrm{BE}$ & 2 & 112.69 & 112.69 & 70.25 & & 7,15 & $11.8 \%$ & \\
\hline & & 178 & & 10. & & & & \\
\hline in & 4.76 & 5 & & 1.4 & & & $.4 \%$ & \\
\hline & 656.27 & & 74.06 & 54.16 & & 2,61 & $10.0 \%$ & \\
\hline & 0 & & 0 & & & & & \\
\hline & 132.54 & 94 & 94 & 1.3 & & $1,886.82$ & $2.3 \%$ & \\
\hline$-C l A$ & 145.97 & 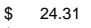 & 47 & 8.0 & & 505.20 & $4 \%$ & \\
\hline & & & & & & & & \\
\hline & & 73 & 82 & 0.2 & & & $.9 \%$ & \\
\hline & & $\$ 2,72$ & 2,8 & $\$ 1$ & & & & \\
\hline & & & & & & & & \\
\hline & $36,712.50$ & $\$ 723$ & 795 & 12.6 & & 5,95 & $5 \%$ & \\
\hline$-c$ & & $\$$ & & & & & $\%$ & \\
\hline & 714.00 & $\$ 5,890.50$ & 00.04 & $\$ 2$ & &, 486.03 & $18.6 \%$ & \\
\hline & & 473 & 473 & 6.6 & & & $16.4 \%$ & \\
\hline DRODS I & & $\$$ & & 1.6 & & & & \\
\hline & & & & & & & & \\
\hline & 3 & $\$ 4,4$ & 3 & $\$ 2,830.6$ & & & 2 & \\
\hline & & & & & & & & \\
\hline & & & & & & & & \\
\hline & & $\$$ & & 0. & & & $4.7 \%$ & \\
\hline & 18,080 & $\$ 3,607$. & $\$ 4,071.56$ & $\$ 2,365.77$ & & $3,141.23$ & 22.5 & \\
\hline & & & & & & & & \\
\hline & & $\$$ & & $\$$ & & & & \\
\hline & $\$ 13,53$ & $\$ 1,70$ & $\$ 1,7 \varsigma$ & $\$ 1,644$ & & 2,027 & 13.2 & \\
\hline & & 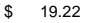 & 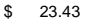 & $\$$ & & & & \\
\hline & & 5 & & 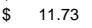 & & & & \\
\hline & 1,282 & 117 & 138 & 99 & & 4,48 & & \\
\hline & & 16 & 16 & & & & & \\
\hline & & & & & & & & \\
\hline & 129 & 5.90 & 99 & 1.3 & & 4 & & \\
\hline WAT & 3 & & 0.05 & .27 & & & & \\
\hline
\end{tabular}

